\title{
Blanching effect on physicochemical and functional properties of flours processed from peeled and unpeeled white-fleshed sweet potato Algerian cultivar
}

\author{
Louiza BELKACEMI ${ }^{1,2^{*}}$ (D)
}

\begin{abstract}
White sweet potato has high potential for flour production whose using in food preparations depends on its functional characteristics which in turn depend on variety, pretreatment methods and processing steps. This study investigated the effect of unpeeling and blanching on the chemical composition and functional properties of flour produced from white fleshed sweet potato Algerian cultivar. Sweet potato tubers were divided into two batches: a manually peeled batch and the unpeeled one, which were trimmed and soaked in water during $15 \mathrm{~min}$. Each batch was then divided into two equal parts: one part was blanched in water at $100{ }^{\circ} \mathrm{C}$ for $5 \mathrm{~min}$, the second part remained non-blanched. All samples were dried at $60^{\circ} \mathrm{C}$ during 24 hours. The flours were analyzed for proximate composition, polyphenol and tannin content, and functional properties. Flour processed from unpeeling sweet potato exhibited higher $(\mathrm{p}<0.001)$ lipid, starch, fiber, polyphenol and tannin content. Blanching decreased significantly polyphenols about $39 \%$ and $30 \%$ and tannins about $48 \%$ and $63 \%$, respectively in unpeeled and peeled blanched SP-based flours. Finally, combination of both unpeeling and blanching increased water absorption capacity, swelling power, water solubility, emulsifying capacity of sweet potato flour which are interesting as properties in various food products.
\end{abstract}

Keywords: sweet potato algerian cultivar; blanching; unpeeling; flour; chemical composition; functional properties.

Practical Application: Improving functional properties of white fleshed reddish-purple skinned sweet potato flour.

\section{Introduction}

The sweet potato (Ipomoea batatas L. Lam) is one of the most consumed edible plants in the world (Krochmal-Marczak et al., 2020). It represents the seventh most important food crop in the world (Mohan et al., 2016) and the fifth-most important one in developing countries (Kaur \& Sandhu, 2016). Sweet potato (SP) is utilized in various forms in different parts of the world. It is consumed as raw, boiled, fried, steamed or further processed into various foods such as snacks, frozen and canned foods (Dereje et al., 2020). This tuberous-rooted perennial plant has emerged among other food crops due to its special nutrient composition (van Chuyen \& Eun, 2013). In fact, sweet potatoes are highly nutritious vegetables with a strong potential to contribute to better nutritional quality of human diets around the world (Truong et al., 2018). In addition to its high content of carbohydrates with low glycemic index (van Chuyen \& Eun, 2013), sweet potato is rich in dietary fiber, minerals, vitamins (Senanayake et al., 2013) and antioxidants such as phenolic acids and $\beta$-carotene (Ji et al., 2015; Truong et al., 2018). Further its nutritional benefits, sweet potato is known for its wide range of agronomic advantages such as wide ecological adaptability, low input requirements and shorter growing period with a high yield (Olatunde et al., 2015). Nevertheless, sweet potatoes are highly perishable and difficult to store. Its shelf life does not exceed a few weeks after harvest and its storage on farms is therefore difficult (van Oirschot et al., 2003; Kihurani \& Kaushal, 2016). The preference is to store fresh sweet potato tubers in a cool store (Krochmal-Marczak et al., 2020) with controlled air relative humidity (85 to 95\%) (Sugri et al., 2017). These conditions could only be fulfilled with advanced, expensive and workforce consuming equipment (Ndangui et al., 2014). In addition, storage affects the carbohydrates, proximate and functional properties of stored sweet potato (Sugri et al., 2017; Krochmal-Marczak et al., 2020). The development of appealing processed products from sweet potatoe will play a major role in addressing the challenges faced with storing and transporting the raw sweet potato roots in developing countries (Ngoma et al., 2019) and in raising awareness on its potential benefits (Saleh et al., 2018). Sweet potato is a tuber crop with high potential for flour production. It represents an adequate and cheap substitute for wheat in the production of wheat-based products such as pasta-type products and bakery products (Olatunde et al., 2019). Moreover, it can also be used to improve food products by enhancing color, flavor, natural sweetness and supplementing with nutrients (Ahmed et al., 2011).

Using sweet potato flour in food preparations depends on its functional characteristics which in turn depend on variety, pretreatment methods and processing steps (Chikpah et al., 2020; Dereje et al., 2020). Hydrothermal pretreatment of sweet potato by short-time blanching is commonly used on sweet potato to preserve the quality of extracted flour (Ndangui et al., 2014). Peeling is another process that influences SP flour nutritional composition and functional characteristics (Chikpah et al., 2020; Shaari et al., 2021). Using the whole sweet potato including root peel maximizes 
health potential and represents the advantage of reducing the amount of food waste (Wang et al., 2016). The combination of both processes would modify further the SP flour physicochemical and functional properties whose determination is important in the prediction of its uses and the quality of the final products.

White fleshed reddish-purple skinned sweet potato is the predominant variety in Algeria. It is consumed fried, boiled or used to produce traditional jam and is not processed into flour. So, there is lack of knowledge on physicochemical and functional properties of flour processed from this variety. Therefore, this study was conducted to evaluate the effect of unpeeling and hydrothermal pretreatment by blanching on chemical composition and functional properties of flour processed from local sweet potato in order to determine its suitability as ingredient in food products.

\section{Materials and methods}

\subsection{Sweet potato samples}

About $18 \mathrm{~kg}$ of non-infested, fresh and mature white fleshed reddish-purple skinned sweet potato roots (Ipomoea batatas Lam) were purchased from wholesale fruits and vegetables market (Oran, Algeria) in December 2020.

\subsection{Sweet potato pretreatment and flour processing}

Sweet potato tubers were processed into flours as illustrated in Figure 1 . The sweet potato tubers were washed manually with tap water to remove soil particles and then divided into two batches: a manually peeled batch and the unpeeled one. Both batches were trimmed into thin slices using a domestic slicer. The slices of each batch were soaked in water during $15 \mathrm{~min}$ to prevent or limit discoloration (James et al., 2013) and then divided into two equal parts: one part was blanched in water at $100^{\circ} \mathrm{C}$ for $5 \mathrm{~min}$ and then immediately immersed in cold water, the second part remained non-blanched. After draining, all samples were dried at $60{ }^{\circ} \mathrm{C}$ during 24 hours. Dried sweet potato slices were then milled and sieved through $250 \mu \mathrm{m}$ sieve to obtain uniform size flour. The flours were packed into polyethylene bags and stored in a dry cabinet at $25 \pm 2{ }^{\circ} \mathrm{C}$ for analysis.

\subsection{Physicochemical analysis}

\section{Proximate composition}

The flours were analyzed for their moisture, ash, crude protein, crude fat and crude fiber contents according to the method described by Association of Official Analytical Chemists

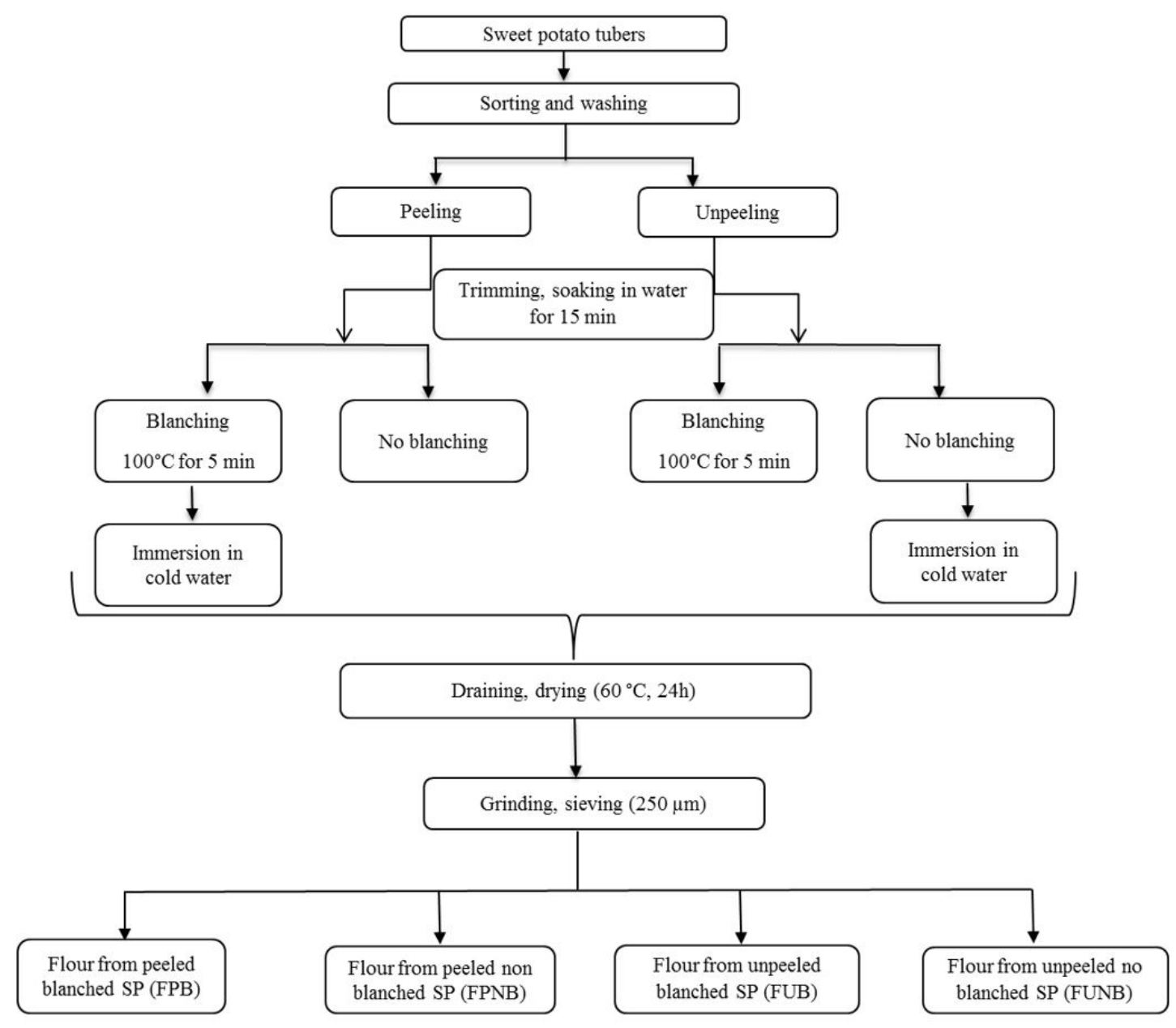

Figure 1. Flow chart for processing white fleshed sweet potato flours. 
(2010). Soluble sugars and starch were extracted according to Maness (2010) and their determination was performed according to DuBois et al. (1956) method.

\section{Color analysis}

The color parameters $\mathrm{L}^{*}, \mathrm{a}^{*}$ and $\mathrm{b}^{*}$ of each SP flour were determined using a Chroma meter (KONICA MINOLTA, CR-410, Japan). After calibration of the instrument with manufacturer's standard, a glass cell containing SP flour was placed above the light source. The $L^{*}, a^{*}$ and $b^{*}$ color values were recorded automatically.

\section{pH determination}

The $\mathrm{pH}$ values were measured according to Ngoma et al. (2019). About $10 \mathrm{~g}$ of each flour sample was mixed with $100 \mathrm{~mL}$ distilled water and then left at room temperature for $30 \mathrm{~min}$. The $\mathrm{pH}$ was measured using a calibrated $\mathrm{pH}$ meter (Adwa AD $1200 \mathrm{pH} / \mathrm{mV} / \mathrm{ISE}$, Romania).

\section{Polyphenol and tannin determination}

Total phenols and tannins were extracted according to Chikpah et al. (2020) with slight modifications. Briefly, $2 \mathrm{~g}$ of flour was dispensed into $20 \mathrm{~mL}$ of acidified methanol $(1 \% \mathrm{HCl})$. The mixture was homogenized in Ultraturax homogenizer during $2 \mathrm{~min}$ and then stirred during $20 \mathrm{~min}$ on magnetic stirrer. The mixture was incubated in darkness at room temperature for $24 \mathrm{~h}$ and then centrifuged at $3000 \mathrm{~g}$ for $10 \mathrm{~min}$. The supernatant was collected and stored at $4{ }^{\circ} \mathrm{C}$, and the residue was extracted again for $24 \mathrm{~h}$ following the same procedure. The supernatants were pulled for total phenol and tannin content determination. Total phenolic content (TPC) was determined according to the method described by Singleton et al. (1999) and was expressed as $\mathrm{mg}$ gallic acid equivalent (GAE)/100 g flour. The tannin content determination was carried out according to the method established by Price et al. (1978) and the results were expressed as $\mathrm{mg}$ catechin equivalent (CE)/100 g flour.

\subsection{Functional properties}

\section{Bulk density}

This parameter was carried out according to the method of Kaur \& Singh (2005). Ten grams of SP flour were placed in a $50 \mathrm{~mL}$ graduated cylinder which was carefully tapped 10 times. Bulk density was calculated by dividing the weight of the flour by the volume of the flour.

\section{Swelling power and water solubility}

Swelling power (SWP) and water solubility (WS) of the flour were estimated as described by Chikpah et al. (2020). A pre-weighted centrifuge tube (W1) containing $2 \mathrm{~g}$ of flour and $25 \mathrm{~mL}$ of distilled water was heated in a water bath at $60^{\circ} \mathrm{C}$ for $30 \mathrm{~min}$, with constant stirring. The slurry was centrifuged at $4000 \mathrm{rpm}$ for $30 \mathrm{~min}$ (SIGMA, D-37520 Osterode am Harz, 2-16KL, Germany), and then the supernatant was transferred into a pre-weighed evaporating dish (W2) and dried at $105^{\circ} \mathrm{C}$ to constant weight (W3). The water solubility was calculated as follow (Equation 1):

$\boldsymbol{W S}(\%)=\frac{\left(W_{3}-W_{2}\right)}{\text { Initial sample weight }} * 100$

The tube containing the residue after centrifugation was weighted (W4) and the swelling power was obtained by the formula (Equation 2):

$\operatorname{SWP}(g / g)=\frac{\left(W_{4}-W_{1}\right)}{\text { Initial sample weight }}$

\section{Water absorption capacity}

The method of Chikpah et al. (2020) was followed to measure the water absorption capacity of SP flours. Approximately, $500 \mathrm{mg}$ of flour sample was weighed in a conical graduated centrifuge tube and dispersed in $5 \mathrm{~mL}$ of distillated water. The mixture was vortexed for $1 \mathrm{~min}$, allowed to stand for $30 \mathrm{~min}$ at room temperature, and then centrifuged at $4000 \mathrm{rpm}$ for $30 \mathrm{~min}$. The supernatant was gently poured in a pre-weighted tube (W1) and the final weight of the centrifuge tube containing the sample after drainage of water was measured and noted (W2). The water absorption capacity (WAC) was expressed in grams of water absorbed per 100 grams of flour (Equation 3):

$\boldsymbol{W A C}(\%)=\frac{\left(\boldsymbol{W}_{2}-\boldsymbol{W}_{1}\right)}{\text { Initial sample weight }} * 100$

\section{Oil absorption capacity}

Oil absorption capacity was measured according to Chikpah et al. (2020). About of $500 \mathrm{mg}$ of flour (W1) was placed into a pre-weighted centrifuge tube (W2), then $5 \mathrm{~mL}$ of oil was added and the mixture was vortexed for $30 \mathrm{~s}$ and allowed to stand for $30 \mathrm{~min}$ at room temperature. Subsequently, the mixture was centrifuged for $30 \mathrm{~min}$ at $4000 \mathrm{rpm}$, then the unabsorbed oil was drained carefully, and the weight of the tube containing the sample was determined and noted (W3). The oil absorption capacity $(\mathrm{OAC})$ was calculated by the following Equation 4 :

$\boldsymbol{O A C}(\%)=\frac{\boldsymbol{W} 3-(\boldsymbol{W} 2+\boldsymbol{W} 1)}{\boldsymbol{W}_{1}} * 100$

\section{Least gelation concentration}

The least gelation concentration (LGC) of SP flours was determined according to Kaur \& Singh (2005) method. Sample suspensions of $2-20 \%(\mathrm{w} / \mathrm{v})$ of each flour were prepared in distilled water and the suspension was transferred into a test tube. The suspensions were heated for $1 \mathrm{~h}$ in boiling water and then cooled under cold running water. The tubes were then placed at $4{ }^{\circ} \mathrm{C}$ for $2 \mathrm{~h}$. The LGC is the concentration above which the sample did not fall or slip when the test tube was inverted. 


\section{Foaming capacity and stability}

The foaming capacity (FC) and foaming stability (FS) were determined by the method reported by Kaur \& Singh (2005). Fifty milliliters of a $3 \%, 5 \%, 7 \%$ and $10 \%(\mathrm{w} / \mathrm{v})$ dispersion of flour sample in distilled water were homogenized for 2-3 min using homogenizer. The blend was immediately transferred into a graduated cylinder and the homogenizer cup was rinsed with $10 \mathrm{~mL}$ distilled water which was then added to the graduated cylinder. The foaming capacity was expressed as a percentage increase in volume. The foam volume was recorded 1 hour after whipping to determine the foam stability of the initial foam volume.

\section{Emulsifying capacity and stability}

Emulsifying capacity (EC) and emulsifying stability (ES) were performed according to the method described by Kaur \& Singh (2005) with slight modifications. Flour sample (3.5 g) was homogenized for $30 \mathrm{~s}$ in $50 \mathrm{~mL}$ cold distillated water $\left(4^{\circ} \mathrm{C}\right)$ in a homogenizer. Soybean oil $(50 \mathrm{~mL})$ was added, and the mixture was homogenized again for $60 \mathrm{~s}$. The emulsion was divided equally into two $50 \mathrm{~mL}$ centrifuge tubes and centrifuged at $1300 \mathrm{~g}$ for $15 \mathrm{~min}$. Emulsifying activity was calculated as follow (Equation 5):

$$
E C(\%)=\frac{\text { Height of emulsion layer }}{\text { Height of whole layer }} * 100
$$

The emulsion stability was determined using the samples prepared for measurement of emulsifying activity. They were heated for $30 \mathrm{~min}$ at $80{ }^{\circ} \mathrm{C}$, cooled at room temperature and then centrifuged at $1100 \mathrm{~g}$ for $5 \mathrm{~min}$. The emulsion stability was expressed as the $\%$ of emulsifying activity remaining after heating.

\section{Alpha-amylase activity}

Alpha-amylase activity was determined with the Hagberg falling number instrument (Partens Instrument) based on ISO 3039-2009 method (International Organization for Standardization, 2009).

\subsection{Statistical analysis}

The assays were performed three times $(\mathrm{n}=3)$ and the results were expressed as mean \pm standard deviation (SD). The assays were compared by using one-way analysis of variance (ANOVA), followed by Duncan's post-hoc test. $\mathrm{P}<0.05$ indicates statistical significance. All statistical analyses were performed using SPSS Statistic 20.0 software.

\section{Results and discussion}

\subsection{Proximate composition}

The proximate composition is reported in Table 1. The moisture and the ash content differed significantly between the four flours $(\mathrm{p}<0.001)$. The moisture of flours did not exceed $11 \%$ and ranged from $9.55 \%$ to $10.72 \%$ which is recommended for long term storage (Olatunde et al., 2019). It is well established that moisture superior to $12 \%$ in food products favorites microbial growth accelerating thereby spoilage (Ndangui et al., 2014). It seemed that drying at $60^{\circ} \mathrm{C}$ during $24 \mathrm{~h}$ is suitable to achieve the appropriate moisture providing stability to flour during storage, if properly stored under good conditions. Ash content in flour is among the parameter taken in consideration in the assessment of flour quality and defining its use in baked products. High amount of ash in flour can affect its technical quality because of a darker color and greater activity of proteolytic and amylolytic enzymes (Czaja et al., 2020). The ash of the SP flours ranged from 1.22 to $1.48 \%$ which complies with the regulatory standard of not more than $1.5 \mathrm{~g} / 100 \mathrm{~g}$ (Alamu et al., 2021). As expected, blanching and peeling exerted a significant effect $(\mathrm{P}<0.001)$ on ash content of the SP flours. The least ash contents recorded in blanched sweet potato based-flours were due to the leaching during blanching pretreatment (Jangchud et al., 2003; Ndangui et al., 2014). Nevertheless, the blanching did not reduce intensely the mineral content of the flours since the decrease was only about 10 and $12 \%$ in unpeeled and peeled SP-based flours, respectively. The unpeeled SP produced flours with higher ash content compared to flours processed from peeled SP. This is related to the presence of inorganic nutrients such as potassium, sodium, calcium, phosphorus, and magnesium in the peel of sweet potato (Shaari et al., 2021).

Sweet potato proteins content is generally not very high; however, they have good nutritional, functional, and health carerelated characteristics (Mu et al., 2017). Protein content of peeled SP-based flours was higher than the unpeeled SP-based flours which is in consistent with other studies (Chikpah et al., 2020; Shaari et al., 2021). The crude protein content ranged between 5.83 and $6.28 \%$ which was low compared to that in orange fleshed (Chikpah et al., 2020) and purple fleshed (Shaari et al., 2021) sweet potato flour, but higher than that reported by other studies (Senanayake et al., 2013; Ohizua et al., 2017; Oloniyo et al., 2021). The protein content of agricultural products depends not only on varieties but also varies with environmental location (Dereje et al., 2020). Overall, sweet potato flour produced from white sweet potato contained a lower level of protein than common wheat flour (Adams et al., 2017).

The crude fat content was affected only by peeling $(\mathrm{p}<0.001)$. The higher content of fat in unpeeled SP based-flours could be explained by the lipid nature of carotenoids contained in the peel. Besides, the fat content was lower in blanched SP flours due probably to carotenoids thermal degradation. The present results agree with those of Shaari et al. (2021) who found that peeling decreased the fat content of sweet potato flour.

The soluble sugars content was almost similar in all flours with no statistically significant difference $(\mathrm{p}>0.05)$. Their content did not exceed $6 \%$ which could indicate the freshness of the SP tubers used in the present study. In fact, delayed harvesting time and storage increase significantly total soluble sugar content of sweet potato (Adu-Kwarteng et al., 2014; Albuquerque et al., 2018). The starch content of the different SP flours (31\% - 61\%) was in the range reported by Jangchud et al. (2003) (36.6-75.0\%) but lower compared to other studies (Olatunde et al., 2019). Sweet potato based-flour starch content differs according to variety and environmental variations (Shaari et al., 2021) and processing 
methods (Fetuga et al., 2014). Moreover, starch content differed significantly from each other $(\mathrm{p}<0.001)$ according to blanching and peeling processes. The FUB presented the highest starch content followed by FPB, FUNB and then the FPNB which displayed the half content of that found in FUB. It seems that starch content was not affected negatively by blanching treatment contrary to that reported in Ndangui et al. (2014) study. It appears that blanching effect on starch content depends upon SP varieties since Olatunde et al. (2019) reported a lowering starch content by blanching in the studied varieties except for EX-OYUNGA one. Blanching seemed to preserve starch from hydrolysis which could be explained by the heat inactivation of $\alpha$-amylase. In addition to blanching process, the peeling had a significant effect on starch content. The highest values were recorded in flour processed from unpeeled SP. Starch yield extraction is strongly dependent on peeling and the highest yield of starch was obtained from unpeeled potato (Nawaz et al., 2020).

The crude fiber content in the flours ranged from 0.83 to $1.63 \%$ which was low compared to other studies (Olatunde et al., 2019; Ohizua et al., 2017; Truong et al., 2018). However, flours from unpeeled SP had comparable fiber content to that reported by Fetuga et al. (2014) which ranged between 1.30-1.65\%. Low fiber content in the present flours could present an industrial advantage since high fiber content may present processing challenges to the food industry, although the use of dietary fiber-rich products may be of nutritional benefit (Mais \& Brennan, 2008). The crude fiber content was affected only by the peeling process $(\mathrm{p}<0.05)$. Peeling reduced crude fiber in FPB and FPNB about $36 \%$ and $44 \%$ compared to those recorded in FUB and FUNB, respectively. The amount of loss in crude fiber as affected by the peeling was somewhere comparable to that described by Shaari et al. (2021). This author suggested that unpeeling is the best way to maintain the high fiber content of sweet potato for good health. Loss in crude fiber was also observed in blanched SP based-flours. Some pretreatments involving leaching such as blanching and parboiling decreased the crude fiber content of SP flour especially the soluble ones (Jangchud et al., 2003).

\subsection{Polyphenol and tannin content}

The purpose of determining total phenol and tannins measurement was to assess their content both as anti-nutritional compounds and as nutraceutical. In fact, phenolic and tannins considered as anti-nutrients are now regarded as having high medicinal properties (Abong et al., 2020). Phenolic compounds from SP tuber decrease oxidative stress and enhance antioxidant defense (Anastácio \& Carvalho, 2013). Therefore, conversion of fresh tubers into flours through appropriate techniques is quite important to preserve the bioactive compounds contained in the raw material (Khanh et al., 2018). The TPC recorded in flour samples (Table 1) ranged from 53.15 to $132.58 \mathrm{mgGAE} / 100 \mathrm{~g}$, which were lower than those reported in other studies (Khanh et al., 2018; Chikpah et al., 2020; Oloniyo et al., 2021); whereas, Abong et al. (2020) did not detected polyphenols in white fleshed SP from Kenya. Oke \& Workneh (2013) reported that a large variation in phenolic content is observed among sweet potato varieties. Furthermore, these variations could be related to environmental conditions. Processing SP affected the amount of total phenol content (TPC) which was higher in unpeeled sweet potato basedflours compared to those processed from peeled SP $(\mathrm{p}<0.001)$. Sweet potato peels possess high levels of phenolics (Anastácio \& Carvalho, 2013). The decreased amount of TPC in peeled SP based-flours could be not only due to skin removal but also to the enzymatic reactions that occur during peeling and which explain the various degrees of losses of phenolic compounds (Amagloh et al., 2021). Further the peeling effect, blanching had a significant effect on TPC which decreased about $39 \%$ and $30 \%$ in unpeeled and peeled blanched SP-based flours, respectively. Leaching can occur during blanching, since the majority of phenolic compounds are water-soluble (Amagloh et al., 2021). Both peeling and blanching affected significantly $(\mathrm{p}<0.001)$ tannin content which varied according to the process methods. Peeling decreased the tannin content about $28 \%$ and $49 \%$ in nonblanched and blanched SP based-flours, respectively. This proves the richness of SP skin with these compounds. In Dako et al. study (2016), tannins were accumulated in the outer skin layer of yellow sweet potato variety and $t$ were removed by peeling with the outer skin layer of the root. Blanching contributed also to the tannin content lowering probably because they are thermolabile antioxidants that are highly soluble in water (Dao et al., 2021). In fact, the decrease reached $48 \%$ and $63 \%$ in unpeeled and peeled SP based-flours, respectively. Finally, the tannin amount contained in SP flours is acceptable seeing that the toxicity effects of the tannin may not be significant since

Table 1. Chemical composition of sweet potato flours.

\begin{tabular}{|c|c|c|c|c|}
\hline Flours & FPB & FPNB & FUB & FUNB \\
\hline Moisture (\%) & $10.23 \pm 0.03^{b}$ & $10.72 \pm 0.03^{\mathrm{a}}$ & $10.12 \pm 0.04^{\mathrm{c}}$ & $9.55 \pm 0.01^{\mathrm{d}}$ \\
\hline Ash (\%) & $1.22 \pm 0.005^{\mathrm{d}}$ & $1.38 \pm 0.005^{\mathrm{b}}$ & $1.33 \pm 0.01^{\mathrm{c}}$ & $1.48 \pm 0.005^{\mathrm{a}}$ \\
\hline Proteins (\%) & $5.93 \pm 0.01^{c}$ & $6.28 \pm 0.025^{\mathrm{a}}$ & $5.83 \pm 0.02^{\mathrm{d}}$ & $6.22 \pm 0.03^{\mathrm{b}}$ \\
\hline Lipids (\%) & $0.50 \pm 0.00^{\mathrm{b}}$ & $0.55 \pm 0.05^{\mathrm{b}}$ & $0.75 \pm 0.05^{\mathrm{a}}$ & $0.8 \pm 0.1^{\mathrm{a}}$ \\
\hline TSS (\%) & $5.50 \pm 0.23$ & $4.74 \pm 0.09$ & $6.03 \pm 0.50$ & $5.42 \pm 1.39$ \\
\hline Starch $(\%)$ & $54.32 \pm 0.18^{\mathrm{b}}$ & $31.51 \pm 4.02^{\mathrm{d}}$ & $60.97 \pm 1.49^{\mathrm{a}}$ & $38.94 \pm 1.26^{c}$ \\
\hline Crude fiber (\%) & $0.83 \pm 0.02^{b}$ & $0.91 \pm 0.06^{\mathrm{b}}$ & $1.29 \pm 0.48^{\mathrm{ab}}$ & $1.63 \pm 0.3^{\mathrm{a}}$ \\
\hline TPC (mgGAE/100 g) & $53.15 \pm 5.66^{c}$ & $76.25 \pm 9.35^{b}$ & $80.95 \pm 2.3^{b}$ & $132.58 \pm 7.12^{\mathrm{a}}$ \\
\hline Tannin (mgCE/100 g) & $34.52 \pm 6.64^{c}$ & $94.58 \pm 19.32^{\mathrm{b}}$ & $68.11 \pm 10.71^{\mathrm{b}}$ & $131.54 \pm 22.68^{\mathrm{a}}$ \\
\hline $\mathrm{pH}$ & $5.73 \pm 0.05^{\mathrm{b}}$ & $5.86 \pm 0.02^{\mathrm{a}}$ & $5.68 \pm 0.01^{\mathrm{b}}$ & $5.73 \pm 0.00^{\mathrm{b}}$ \\
\hline
\end{tabular}

Each value is expressed as mean $\pm \mathrm{SD}(\mathrm{n}=3)$. Values followed by different letters are significantly different at $\mathrm{p}<0.05$. TSS=total soluble sugars, TPC $=$ total phenol content. 
the total acceptable tannic acid daily intake for a man is $560 \mathrm{mg}$ (Dako et al., 2016). Moreover, it is reported that daily intake of tannins below the range of 1.5-2.5 $\mathrm{g}$ is safe for consumption and does not cause any side effects (Sharma et al., 2019).

\section{$3.3 \mathrm{pH}$ values}

The $\mathrm{pH}$ values of the different flours were above 5.5 and slightly below 6 (Table 1) indicating a good quality of the SP flours. The $\mathrm{pH}$ values were comparable to that reported by Teye et al. (2018) who considered it (5.5) within the acceptable level for flours.

\subsection{Color parameters}

The hunter color $\mathrm{L}^{*}, \mathrm{a}^{*}$ and $\mathrm{b}^{*}$ values of SP flour (Table 2 ) were affected both by peeling and blanching pretreatment $(\mathrm{p}<0.001)$. All flours exhibited high $\mathrm{L}^{*}$ values indicating that they were light in appearance; nevertheless, flours from both blanched SP had higher $\mathrm{L}^{*}$ mean values compared to those from non-blanched SP. It is reported that blanching is effective in improving the color of SP dried varieties (Oke \& Workneh, 2013). Increasing in lightness of SP blanched based-flours is due to the blanching inactivation of polyphenol oxidase and peroxidase, which are responsible for the enzymatic browning reaction (Nascimento \& Canteri, 2018). In addition, soaking SP slices after cutting prevented their browning. Unpeeling decreased the lightness of flours which was due to the reddish color of the SP peels. Besides, flours from unpeeled SP had the highest $\mathrm{a}^{*}$ value due to the presence of carotenoids (Ameny \&
Wilson, 1997) which were probably subjected to degradation during blanching since the $\mathrm{a}^{*}$ value of flour from unpeeled blanched SP was about half of that found in flour from unpeeled non blanched SP. Blanching affected also the $b^{\star}$ values which were lower in both flours processed from peeled and unpeeled SP. So, the non-blanched SP produced flours (FPNB and FUNB) which toward yellow.

\subsection{Functional properties}

The functional properties of the different SP flours are shown in Table 3. Functional characteristics such as bulk density, swelling power, water absorption capacity, water solubility, foaming and emulsifying capacities are very important attributes that indicate the usefulness of flour as ingredients (Teye et al., 2018). The bulk density (BD) of flours differed significantly $(\mathrm{p}<0.05)$ and ranged from $0.714 \mathrm{~g} / \mathrm{cm}^{3}$ to $0.769 \mathrm{~g} / \mathrm{cm}^{3}$. The SP flours in the present study are appropriate as ingredient in food formulations. In fact, high $\mathrm{BD}$ of the present flour suggests their suitability for use in food preparations (Chandra et al., 2015) but is not advantageous in the preparation of weaning food formulations, which require low bulk density flour (Akubor, 1997). Indeed, lower BD promotes digestibility of the formula, especially among children with immature digestive system (James et al., 2013).

The flours processed from unpeeled SP recorded a higher water absorption capacity (WAC) and swelling power (SWP) percentage $(\mathrm{p}<0.001)$ probably due to the presence of crude fiber known for their capacity to absorb water and swell. Generally, WAC and SWP properties are related to amount of both soluble

Table 2. Color attributes of sweet potato flours.

\begin{tabular}{crrrr}
\hline Flours & FPB & FPNB & FUB \\
\hline L $^{*}$ & $87.49 \pm 0.09^{\mathrm{a}}$ & $86.21 \pm 0.02^{\mathrm{b}}$ & $83.17 \pm 0.47^{\mathrm{c}}$ \\
$\mathrm{a}^{*}$ & $-0.69 \pm 0.02^{\mathrm{d}}$ & $-0.40 \pm 0.005^{\mathrm{c}}$ & $0.68 \pm 0.06^{\mathrm{b}}$ & $1.42 \pm 0.00^{\mathrm{a}}$ \\
$\mathrm{b}^{*}$ & $11.84 \pm 0.07^{\mathrm{c}}$ & $12.87 \pm 0.14^{\mathrm{b}}$ & $12.79 \pm 0.16^{\mathrm{b}}$ & $13.35 \pm 0.11^{\mathrm{a}}$ \\
\hline
\end{tabular}

Each value is expressed as mean \pm SD $(n=3)$. Values followed by different letters are significantly different at $\mathrm{p}<0.05$.

Table 3. Functional properties of sweet potato flours.

\begin{tabular}{lcccc}
\hline \multicolumn{1}{c}{ Flours } & FPB & FPNB & FUB & FUNB \\
\hline BD (g/cm ${ }^{3)}$ & $0.77 \pm 0.00^{\mathrm{a}}$ & $0.74 \pm 0.02^{\mathrm{ab}}$ & $0.71 \pm 0.00^{\mathrm{b}}$ & $0.74 \pm 0.02^{\mathrm{ab}}$ \\
SWP (g/g) & $3.09 \pm 0.014^{\mathrm{c}}$ & $3.16 \pm 0.013^{\mathrm{b}}$ & $3.18 \pm 0.01^{\mathrm{b}}$ & $3.49 \pm 0.012^{\mathrm{a}}$ \\
WS (\%) & $12.7 \pm 0.7^{\mathrm{b}}$ & $14.85 \pm 0.55^{\mathrm{a}}$ & $14.45 \pm 0.05^{\mathrm{a}}$ & $15.05 \pm 0.05^{\mathrm{a}}$ \\
WAC (\%) & $169.80 \pm 0.40^{\mathrm{c}}$ & $167.70 \pm 0.30^{\mathrm{d}}$ & $237.10 \pm 1.7^{\mathrm{a}}$ & $182.70 \pm 0.30^{\mathrm{b}}$ \\
OAC (\%) & $136.2 \pm 0.20^{\mathrm{a}}$ & $134.60 \pm 0.20^{\mathrm{b}}$ & $130.90 \pm 0.10^{\mathrm{c}}$ & $134.90 \pm 0.90^{\mathrm{b}}$ \\
FC (\%) & $2 \pm 0.0^{\mathrm{c}}$ & $4 \pm 0.0^{\mathrm{a}}$ & $2.5 \pm 0.50^{\mathrm{b}}$ & $4 \pm 0.0^{\mathrm{a}}$ \\
FS (\%) & 0 & 0 & $36.27 \pm 0.98^{\mathrm{b}}$ & 0 \\
EC (\%) & $28.17 \pm 1.24^{\mathrm{c}}$ & $38.83 \pm 0.38^{\mathrm{a}}$ & 0 & $29.41 \pm 0.0^{\mathrm{c}}$ \\
ES (\%) & 0 & $31.20 \pm 1.41$ & $12 \pm 00$ & 0 \\
LGC (\%) & $14 \pm 0.0$ & $14 \pm 0.0$ & & $12 \pm 0.0$ \\
Alpha-amylase activity & & & $72.27 \pm 0.06^{\mathrm{b}}$ & \\
- FN (min) & $85.02 \pm 0.04^{\mathrm{a}}$ & $12.13 \pm 0.06^{\mathrm{d}}$ & $20.62 \pm 0.13^{\mathrm{c}}$ \\
- LN & $1.19 \pm 0.00^{\mathrm{d}}$ & $8.85 \pm 0.05^{\mathrm{a}}$ & $5.05 \pm 0.03^{\mathrm{b}}$
\end{tabular}

Each value is expressed as mean $\pm \mathrm{SD}(\mathrm{n}=3)$. Values followed by different letters are significantly different at $\mathrm{p}<0.05$. $\mathrm{BD}=$ bulk density, $\mathrm{SWP}=\mathrm{swelling}$ power, $\mathrm{WS}=$ water solubility, $\mathrm{WAC}=$ water absorption capacity, $\mathrm{OAC}=$ oil absorption capacity, $\mathrm{FC}=$ foaming capacity, $\mathrm{FS}=$ foaming stability, $\mathrm{EC}=\mathrm{emulsifying}$ capacity, $\mathrm{ES}=$ emulsifying stability, $\mathrm{LGC}=$ least gelation concentration, $\mathrm{FN}=$ falling number, $\mathrm{LN}$ = liquefaction number. 
and insoluble dietary fiber (Wang et al., 2017). Insoluble fibers present in unpeeled SP flours retain water and swell contributing consequently to reduce food intake and promote satiety (Tan et al., 2016). In parallel, WAC and SWP of fibers are associated with the rheological attributes and the palatability of food products experienced by consumers (Nevara et al., 2021). Moreover, the high SWP has the advantage that only a small amount of flour will be required to achieve significant swelling, this has implications for commercial purposes in terms of profit expectations (Fetuga et al., 2014). The blanching decreased slightly the SWP and water solubility (WS) of flours and increased significantly the WAC especially in FUB. The high WAC indicates the integrity of the starch in aqueous dispersion (Ndangui et al., 2014). Swelling power of flour is associated with starch capacity to imbibe water and swell and it gives the behavior of starch in the food systems (Afoakwa et al., 2012). The starch of sweet potato is composed of a mixture of amylose and amylopectin and is reported to possess an A-type with high swelling property (Kaur \& Sandhu, 2016). The high WAC of FUNB flour suggests that this later can be used in formulation of some foods such as sausage, dough, processed cheese and bakery products (Chandra et al., 2015) which would enrich processed foods with fibers improving thereby their nutritional value. Moreover, the flours displaying the high SWP were those showing high WS which is another attribute that would be useful for the production of bakery and confectionery products (Dereje et al., 2020).

The oil absorption capacity (OAC) measuring the ability of food material to absorb oil is an important property that contributes to increase the mouth feel of foods and improves the palatability and extends the shelf life of baked products (Gitanjali \& Lakhawat, 2019). The OAC varying from $130 \%$ to $136 \%$ was higher than those reported by Gitanjali \& Lakhawat (2019) and slightly lower in Ohizua et al. (2017) study. This difference is explained by SP varieties and pretreatment. Proteins are involved in OAC of flour by entrapping oil by non-covalent bonds such as hydrophobic, electrostatic, and hydrogen bonding (Wang et al., 2017). Increased OAC in peeled blanched SP flour could be due to blanching which enhanced exposition of proteins to interact with oil due to micro-porous nature of the blanched product (Ohizua et al., 2017).

The least gelation concentration (LGC) of flours from unpeeled SP was lower (12\%) compared to that of flours from peeled SP (14\%). It is obvious that fibers contributed to the gel formation since this functional property among other is attributed to plant fibers (Fetuga et al., 2014). Proteins also contribute to gel formation since the LGC can be defined as the lowest concentration of protein where gel remained in the inverted tube (Dereje et al., 2020). A lower gelation property is related to reduce physical competition for water between protein gelation and modified starch which had lower LGC when compared to the native starch (Olu-Owolabi et al., 2011). This supports our previous finding about the fact that blanching of SP did not affect the starch structure of flour since their WAC did not decrease. Finally, the high LGC indicates that more amount will be needed to form gel with sweet potato flour because of its low gelation capacity (Adams et al., 2017).
As functional property, foaming capacity (FC) influences the texture, density, smell, and taste of food, such as ice cream, cake, and bread (Mu et al., 2017). The foaming capacity of flours did not exceed $4 \%$. Most of the studies reported a low FC of sweet potato flours (Akubor, 1997; Adeleke \& Odedeji, 2010; Agbemafle et al., 2014; Ohizua et al., 2017). The low FC of these flours may be due to the low amount of proteins since it depends largely on the protein content of the samples (Godoy et al., 1992; Aluko et al., 2009) as well as the protein type and the degree of protein inactivation (Mu et al., 2017). Finally, the foams of the four flours collapsed within $1 \mathrm{~h}$ of standing at room temperature which indicates that these flours are not suitable in aerated foods.

The emulsifying capacity (EC) of the flours reached values comprised between 28 and $38.8 \%$ which was higher than those reported by other studies (Olapade \& Ogunade, 2014; Adams et al., 2017; Ohizua et al., 2017). Sweet potato proteins are reported to have good emulsifying activity (Mu et al., 2019) and could be used as a natural emulsifier and as a kind of high-quality protein resource (Mu et al., 2017). Their high EC may be due to their globular nature (Ohizua et al., 2017). The peeled non-blanched SP based-flour (FPNB) recorded the highest EC and was the only one which remained stable $(31.2 \pm 1.41 \%)$. Blanching reduces emulsion ability/stability of flour (Oluwalana et al., 2011; Reis, 2017). The FPNB could be suitable as ingredient in meat products batter since EC plays role in such food system where the protein has the ability to bind oil (Adeleke \& Odedeji, 2010).

Alpha-amylase activity in flours was measured in falling number (FN) which is a standard method for evaluating flour a-amylase activity (He et al., 2019). In the present study, all flours exhibited very high FN values ranging from 12 to $85 \mathrm{~min}$. Bakare et al. (2017) found high FN in banana flour ranging between 27 and $39 \mathrm{~min}$. They suggested that the banana flour either possesses little or no endogenous $\alpha$-amylase. At this fact, it was reported that sweet potato contains abundant $\beta$-amylase and a small amount of $\alpha$-amylase (Ikemiya \& Deobald, 1966; Hagenimana et al., 1994) especially in freshly harvested tubers (Ikemiya \& Deobald, 1966). The FN was so high and out of the range (200-300 s) that it was converted in liquefaction number (LN) according to He et al. recommendation (2019). The lowest $\mathrm{LN}$ was recorded in peeled non blanched SP based-flour. It appears that hydrothermal pretreatment reduced further the $\alpha$-amylase activity and thereby decreased the liquefaction of starch in FPB. Blanching pretreatment may either inactivate or limit the a-amylase activity (Bakare et al., 2017). A high FN reflecting a low $\alpha$-amylase activity is imperative to produce good quality flour (Truong et al., 2018); nevertheless, He et al. (2019) indicated that even if a low FN is associated with undesired texture, using a high FN flour does not guarantee excellent baking quality especially for producing bread. Therefore, it seems that SP flours in the present study is not appropriate to bread making since flour with FN greater than 280-300 s produces bread with small volume and dried crumb (Ştefan et al., 2015).

\section{Conclusion}

This study brings insights about the physicochemical quality and functional properties of flours processed from white fleshed reddish-purple skinned sweet potato Algerian cultivar and 
concluded about the significant effect of unpeeling and blanching on these flours. It is established that the unpeeled sweet potato tubers produced flour with a better nutritional composition and functional properties. It enhanced the water absorption capacity, swelling power and emulsifying capacity. In addition, polyphenols and tannins were well-preserved in flours from unpeeled sweet potato which is useful in the human diet, especially that their content was nutritionally acceptable. Blanching at $100{ }^{\circ} \mathrm{C}$ for 5 min decreased to some extent the amount of some nutrients such as lipids, proteins, ash and fibers, but improved water and oil absorption capacity, bulk density and the lightness of flour. Therefore, the combination of unpeeling and blanching pretreatment is recommended for improving the sweet potato flour quality with interesting potential as ingredient in various food products especially those intended to gluten-intolerant persons. Further study should be conducted on the effect of unpeeling and blanching on the antioxidant activities of this sweet potato flour and their anti-nutritional factors.

\section{References}

Abong, G., Muzhingi, T., Okoth, M. W., Ng’ang’a, F., Ochieng’, P. E., Mbogo, D. M., Malavi, D., Akhwale, M., \& Ghimire, S. (2020). Phytochemicals in leaves and roots of selected kenyan orange fleshed sweet potato (OFSP) varieties. International Journal of Food Science, 2020, 3567972. PMid:32083118.

Adams, O. K., Adams, I. M., \& Orungbemi, O. O. (2017). The effect of fermentation on functional properties of sweet potato and wheat flour. African Journal of Food Science and Technology, 8(2), 14-18.

Adeleke, R. O., \& Odedeji, J. O. (2010). Functional properties of wheat and sweet potato flour blends. Pakistan Journal of Nutrition, 9(6), 535-538. http://dx.doi.org/10.3923/pjn.2010.535.538.

Adu-Kwarteng, E., Sakyi-Dawson, E. O., Ayernor, G. S., Truong, V., Shih, F. F., \& Daigle, K. (2014). Variability of sugars in staple-type sweet potato (Ipomoea batatas) cultivars: the effects of harvest time and storage. International Journal of Food Properties, 17(2), 410-420. http://dx.doi.org/10.1080/10942912.2011.642439.

Afoakwa, E. O., Budu, A. S., Asiedu, C., Chiwona-Karltun, L., \& Nyirenda, D. B. (2012). Viscoelastic properties and physico-functional characterization of six high yielding cassava mosaic disease-resistant cassava (Manihot esculenta crantz) genotypes. Journal of Nutrition \& Food Sciences, 2, 1000129.

Agbemafle, R., Sekyere, J. D. O., Otchere, J. K., Acquaye, A., Diabor, E., \& Asi, J. (2014). Effect of different storage methods on the proximate composition and functional properties of cream-skinned sweet potato (Ipomea batatas Lam). Scholars Journal of Engineering and Technology, 2(1), 33-44.

Ahmed, M., Akter, M. S., \& Eun, J. B. (2011). Optimization conditions for anthocyanin and phenolic content extraction form purple sweet potato using response surface methodology. International Journal of Food Sciences and Nutrition, 62(1), 91-96. http://dx.doi.org/10.3 109/09637486.2010.511167. PMid:20858156.

Akubor, P. I. (1997). Proximate composition and selected functional properties of African breadfruit and sweet potato flour blends. Plant Foods for Human Nutrition, 51(1), 53-60. http://dx.doi. org/10.1023/A:1007948400685. PMid:9498694.

Alamu, E. O., Gondwe, T., Ayinde, O., Akinwale, G., Ntawuruhunga, P., Awoyale, W., Abass, A., \& Maziya-Dixon, B. (2021). Physicochemical, microbial, and aflatoxin analyses of selected high-quality cassava flour (HQCF) from the major markets of Zambia. Cogent Food \&
Agriculture, 7(1), 1914906. http://dx.doi.org/10.1080/23311932.2 021.1914906 .

Albuquerque, J. R. T., Ribeiro, R. M. P., Sousa, L. V., Oliveira, G. B. S., Lins, H. A., Barros, A. P. Jr., Santos, E. C., Morais, P. L. D., \& Simões, A. D. N. (2018). Quality of sweet potato cultivars planted harvested at different times of two seasons. Australian Journal of Crop Science, 12(6), 898-904. http://dx.doi.org/10.21475/ajcs.18.12.06.PNE884.

Aluko, R. E., Mofolasayo, O. A., \& Watts, B. M. (2009). Emulsifying and foaming properties of commercial yellow pea (Pisum sativum L.) seed flours. Journal of Agricultural and Food Chemistry, 57(20), 9793-9800. http://dx.doi.org/10.1021/jf902199x. PMid:20560631.

Amagloh, F. C., Yada, B., Tumuhimbise, G. A., Amagloh, F. K., \& Kaaya, A. N. (2021). The potential of sweet potato as a functional food in sub-saharan africa and its implications for health: A review. Molecules, 26(10), 2971. http://dx.doi.org/10.3390/molecules26102971. PMid:34067782.

Ameny, M. A., \& Wilson, P. W. (1997). Relationship between Hunter color values and beta-carotene content in white-fleshed African sweet potatoes (Ipomoea batatas Lam). Journal of the Science of Food and Agriculture, 73(3), 301-306. http://dx.doi.org/10.1002/ (SICI)1097-0010(199703)73:3<301::AID-JSFA726>3.0.CO;2-Z.

Anastácio, A., \& Carvalho, I. S. (2013). Phenolics extraction from sweet potato peels: key factors screening through a Placket-Burman design. Industrial Crops and Products, 43, 99-105. http://dx.doi. org/10.1016/j.indcrop.2012.07.011.

Association of Official Agricultural Chemists - AOAC. (2010). Official Methods of Analysis of Association of Official Analytical Chemists (18th ed.). Washington, DC: AOAC.

Bakare, A. H., Ogunbowale, O. D., Adegunwa, M. O., \& Olusanya, J. O. (2017). Effects of pretreatments of banana (Musa AAA,Omini) on the composition, rheological properties, and baking quality of its flour and composite blends with wheat flour. Food Science \& Nutrition, 5(2), 182-196. http://dx.doi.org/10.1002/fsn3.378. PMid:28265353.

Chandra, S., Singh, S., \& Kumari, D. (2015). Evaluation of functional properties of composite flours and sensorial attributes of composite flour biscuits. Journal of Food Science and Technology, 52(6), 3681-3688. http://dx.doi.org/10.1007/s13197-014-1427-2.<jrn>

Chikpah, S. K., Korese, J. K., Hensel, O., \& Sturm, B. (2020). Effect of sieve particle size and blend proportion on the quality properties of peeled and unpeeled orange fleshed sweet potato composite flours. Foods, 9(6), 740. http://dx.doi.org/10.3390/foods9060740. PMid:32512746.

Czaja, T., Sobota, A., \& Szostak, R. (2020). Quantification of ash and moisture in wheat flour by Raman spectroscopy. Foods, 9(3), 280. http://dx.doi.org/10.3390/foods9030280. PMid:32138384.

Dako, E., Retta, N., \& Desse, G. (2016). Comparison of three sweet potato (Ipomoea batatas (1.) Lam) varieties on nutritional and antinutritional factors. Global Journal of Science Frontier Research: D Agriculture and Veterinary, 16(6), 63-72.

Dao, T. P., Nguyen, D. V., Tran, T. Y. N., Pham, T. N., Nguyen, P. T. N., Bach, L. G., Nguyen, V. H., Do, V. Q., Nguyen, V. M., \& Tran, T. T. (2021). Effects of tannin, ascorbic acid, and total phenolic contents of cashew (Anacardium occidentale L.) apples blanched with saline solution. Food Research, 5(1), 409-416. http://dx.doi.org/10.26656/ fr.2017.5(1).454.

Dereje, B., Girma, A., Mamo, D., \& Chalchisa, T. (2020). Functional properties of sweet potato flour and its role in product development: a review. International Journal of Food Properties, 23(1), 1639-1662. http://dx.doi.org/10.1080/10942912.2020.1818776. 
DuBois, M., Gilles, K. A., Hamilton, J. K., Rebers, P., \& Smith, F. (1956). Colorimetric method for determination of sugars and related substances. Analytical Chemistry, 28(3), 350-356. http://dx.doi. org/10.1021/ac60111a017.

Fetuga, G., Tomlins, K., Henshaw, F., \& Idowu, M. (2014). Effect of variety and processing method on functional properties of traditional sweet potato flour ("elubo") and sensory acceptability of cooked paste ("amala"). Food Science \& Nutrition, 2(6), 682-691. http:// dx.doi.org/10.1002/fsn3.161. PMid:25493186.

Gitanjali \& Lakhawat, S. (2019). Determination of physical and functional properties of orange fleshed sweet potato (Ipomea batatas L.) flour. International Journal of Chemical Studies, 7(4), 420-425.

Godoy, C. V., Tulin, E. E., \& Quevedo, E. S. (1992). Physicochemical properties of raw and blanched taro flours. Journal of Food Processing and Preservation, 16(4), 239-252. http://dx.doi. org/10.1111/j.1745-4549.1992.tb00205.x.

Hagenimana, V., Simard, R. E., \& Vézina, L.-P. (1994). Amylolytic activity in germinating sweet potato (Ipomoea batatas L.) Roots. Journal of the American Society for Horticultural Science, 119(2), 313-320. http://dx.doi.org/10.21273/JASHS.119.2.313.

He, Y., Lin, Y., Chen, C., Tsai, M., \& Lin, A. H. (2019). Impacts of starch and the interactions between starch and other macromolecules on wheat falling number. Comprehensive Reviews in Food Science and Food Safety, 18(3), 641-654. http://dx.doi.org/10.1111/15414337.12430. PMid:33336928.

Ikemiya, M., \& Deobald, H. J. (1966). New characteristic alpha-amylase in sweet potatoes. Journal of Agricultural and Food Chemistry, 14(3), 237-241. http://dx.doi.org/10.1021/jf60145a011.

International Organization for Standardization - ISO. (2009). ISO 3093-1:2009, Wheat, rye and their flours, durum wheat and durum wheat semolina - Determination of the falling number according to Hagberg-Perten. New Zeland: ISO.

James, E. O., Peter, I. A., Charles, N. I., \& Joel, N. (2013). Chemical composition and effect of processing and flour particle size on physicochemical and organoleptic properties of cocoyam (Colocasia esculenta var. esculenta) flour. Nigerian Food Journal, 31(2), 113-122. http://dx.doi.org/10.1016/S0189-7241(15)30084-9.

Jangchud, K., Phimolsiripol, Y., \& Haruthaithanasan, V. (2003). Physicochemical properties of sweet potato flour and starch as affected by blanching and processing. Stärke, 55(6), 258-264. http:// dx.doi.org/10.1002/star.200390053.

Ji, H., Zhang, H. X., Li, H. T., \& Li, Y. C. (2015). Analysis on the nutrition composition and antioxidant activity of different types of sweet potato cultivars. Food and Nutrition Sciences, 6(1), 161-167. http:// dx.doi.org/10.4236/fns.2015.61017.

Kaur, M., \& Sandhu, K. S. (2016). Sweet potato flour and starch. In H. K. Sharma (Ed.), Tropical roots and tubers: production, processing and technology (Chap 11.1, pp. 479-506). New York: John Wiley and Sons. http://dx.doi.org/10.1002/9781118992739.ch11a.

Kaur, M., \& Singh, N. (2005). Studies on functional, thermal and pasting properties of flours from different chickpea (Cicer arietinum L.) cultivars. Food Chemistry, 91(3), 403-411. http://dx.doi.org/10.1016/j. foodchem.2004.06.015.

Khanh, P. T. L., Chittrakorn, S., Rutnakornpituk, B., Tai, H. P., \& Ruttarattanamongkol, K. (2018). Processing effects on anthocyanins, phenolic acids, antioxidant activity, and physical characteristics of Vietnamese purple-fleshed sweet potato flours. Journal of Food Processing and Preservation, 42(9), e13722. http://dx.doi.org/10.1111/ jfpp.13722.
Kihurani, A. W., \& Kaushal, P. (2016). Storage techniques and commercialization. In H. K. Sharma (Ed.), Tropical roots and tubers: production, processing and technology (Chap 6; pp. 253-280). New York: John Wiley and Sons. http://dx.doi.org/10.1002/9781118992739.ch6.

Krochmal-Marczak, B., Sawicka, B., \& Krzysztofik, B. (2020). The effects of temperature on the quality and storage stalibity of sweet potato (Ipomoea batatas L. [Lam]) grown in Central Europe. Agronomy, 10(11), 1665.

Mais, A., \& Brennan, C. S. (2008). Characterisation of flour, starch and fibre obtained from sweet potato (kumara) tubers, and their utilisation in biscuit production. International Journal of Food Science \& Technology, 43(2), 373-379. http://dx.doi.org/10.1111/j.13652621.2007.01652.x.

Maness, N. (2010). Extraction and analysis of soluble carbohydrates. In R. Sunkar (Ed.), Plant stress tolerance, methods in Molecular Biology (Chap 22; pp. 341-370). New York: Humana Press. http://dx.doi. org/10.1007/978-1-60761-702-0_22.

Mohan, C., Prasannakumary, V., \& Nair, A. G. H. (2016). Tropical roots and tubers: impact on environment, biochemical, molecular characterization of different varieties of tropical roots and tubers. In H. K. Sharma (Ed.), Tropical roots and tubers: production, processing and technology (Chap 3, pp. 139-182). New York: John Wiley and Sons. http://dx.doi.org/10.1002/9781118992739.ch3.

Mu, T., Sun, H., Zhang, M., \& Wang, C. (2017). Sweet potato proteins. In T. Mu (Ed.), Sweet potato processing technology (Chap 2, pp.49119). Amsterdam: Elsevier. http://dx.doi.org/10.1016/B978-0-12812871-8.00002-7.

Mu, T., Zhang, M., Arogundade, L. A., \& Khan, N. M. (2019). Sweet potato protein and its hydrolysates. In T. Mu (Ed.), Sweet potato processing technology (Chap 4, pp. 69-115). Amsterdam: Elsevier. http://dx.doi.org/10.1016/B978-0-12-813637-9.00004-1.

Nascimento, R. F., \& Canteri, M. H. G. (2018). Effect of blanching on physicochemical characteristics of potato flour. Horticultura Brasileira, 36(4), 461-465. http://dx.doi.org/10.1590/s0102-053620180406.

Nawaz, A., Ali, S. W., Irshad, S., Irshad, F., Ahmed, A., Sharmeen, Z., \& Khan, K. (2020). Effect of peeling and unpeeling on yield, chemical structure, morphology and pasting properties of starch extracted from three diverse potato cultivars of Pakistan. International Journal of Food Science \& Technology, 55(6), 2344-2351. http://dx.doi. org/10.1111/ijfs.14412.

Ndangui, C. B., Petit, J., Gaiani, C., Nzikou, J., \& Scher, J. (2014). Impact of thermal and chemical pretreatments on physicochemical, rheological, and functional properties of sweet potato (Ipomea batatas lam) flour. Food and Bioprocess Technology, 7(12), 3618-3628. http:// dx.doi.org/10.1007/s11947-014-1361-3.

Nevara, G. A., Muhammad, S. K. S., Zawawi, N., Mustapha, N. A., \& Karim, R. (2021). Dietary fiber: fractionation, characterization and potential sources from defatted oilseeds. Foods, 10(4), 754. http:// dx.doi.org/10.3390/foods10040754. PMid:33918108.

Ngoma, K., Mashau, M. E., \& Silungwe, H. (2019). Physicochemical and functional properties of chemically pretreated Ndou sweet potato flour. International Journal of Food Science, 2019, 4158213. http:// dx.doi.org/10.1155/2019/4158213. PMid:31911929.

Ohizua, E. R., Adeola, A. A., Idowu, M. A., Sobukola, O. P., Afolabi, T. A., Ishola, R. O., Ayansina, S. O., Oyekale, T. O., \& Falomo, A. (2017). Nutrient composition, functional, and pasting properties of unripe cooking banana, pigeon pea, and sweet potato flour blends. Food Science \& Nutrition, 5(3), 750-762. http://dx.doi.org/10.1002/ fsn3.455. PMid:28572965. 
Oke, M. O., \& Workneh, T. S. (2013). A review on sweet potato postharvest processing and preservation technology. African Journal of Agricultural Research, 8(40), 4990-5003.

Olapade, A. A., \& Ogunade, O. A. (2014). Production and evaluation of flours and crunchy snacks from sweet potato (Ipomea batatas) and maize flours. International Food Research Journal, 21(1), 203-208.

Olatunde, G. O., Henshaw, F. O., Idowu, M. A., \& Tomlins, K. (2015). Quality attributes of sweet potato flour as influenced by variety, pretreatment and drying method. Food Science \& Nutrition, 4(4), 623-635. http://dx.doi.org/10.1002/fsn3.325. PMid:27386111.

Olatunde, S. J., Ajayi, O. M., Ogunlakin, G. O., \& Ajala, A. S. (2019). Nutritional and sensory properties of cake made from blends of pigeon pea, sweet potato and wheat flours. Food Research, 3(5), 456-462. http://dx.doi.org/10.26656/fr.2017.3(5).255.

Oloniyo, R. O., Omoba, O. S., \& Awolu, O. O. (2021). Biochemical and antioxidant properties of cream and orange-fleshed sweet potato. Heliyon, 7(3), e06533. http://dx.doi.org/10.1016/j.heliyon.2021. e06533. PMid:33817383.

Olu-Owolabi, B. I., Afolabi, T. A., \& Adebowale, K. O. (2011). Pasting, thermal, hydration, and functional properties of annealed and heat-moisture treated starch of sword bean (Canavalia gladiata). International Journal of Food Properties, 14(1), 157-174. http:// dx.doi.org/10.1080/10942910903160331.

Oluwalana, I. B., Oluwamukomi, M. O., Fagbemi, T. N., \& Oluwafemi, G. I. (2011). Effects of temperature and period of blanching on the pasting and functional properties of plantain (Musa parasidiaca) flour. Journal of Stored Products and Postharvest Research, 2(8), 164-169.

Price, M. L., van Scoyoc, S., \& Butler, L. G. (1978). A critical evaluation of the vanillin reaction as an assay for tannin in sorghum grain. Journal of Agricultural and Food Chemistry, 26(5), 1214-1218. http:// dx.doi.org/10.1021/jf60219a031.

Reis, F. R. (2017). Effect of blanching on food physical, chemical, and sensory quality. In F. R. Reis (Ed.), New perspectives on food blanching (Chap 2, pp. 7-48). Cham: Springer International. http://dx.doi. org/10.1007/978-3-319-48665-9_2.

Saleh, M., Lee, Y., \& Obeidat, H. (2018). Effects of incorporating nonmodified sweet potato (Ipomoea batatas) flour on wheat pasta functional characteristics. Journal of Texture Studies, 49(5), 512-519. http://dx.doi.org/10.1111/jtxs.12319. PMid:29283180.

Senanayake, S. A., Ranaweera, K. K. D. S., Gunaratne, A., \& Bamunuarachchi, A. (2013). Comparative analysis of nutritional quality of five different cultivars of sweet potatoes (Ipomea batatas (L) Lam) in Sri Lanka. Food Science \& Nutrition, 1(4), 284-291. http://dx.doi.org/10.1002/ fsn3.38. PMid:24804032.

Shaari, N., Shamsudin, R., Nor, M. Z. M., \& Hashim, N. (2021). Quality attributes of Malaysia purple-fleshed sweet potato at different peel condition. Agronomy, 11(5), 872. http://dx.doi.org/10.3390/ agronomy11050872.
Sharma, K., Kumar, V., Kaur, J., Tanwar, B., Goyal, A., Sharma, R., Gat, Y., \& Kumar, A. (2019). Health effects, sources, utilization and safety of tannins: a critical review. Toxin Reviews, 2019, 1-13. http://dx.doi. org/10.1080/15569543.2019.1662813.

Singleton, V. L., Orthofer, R., \& Lamuela-Raventos, R. M. (1999). Analysis of total phenols and other oxidation substrates and antioxidants by means of Folin-Ciocalteu reagent. Methods in Enzymology, 299, 152-178. http://dx.doi.org/10.1016/S0076-6879(99)99017-1.

Ştefan, E. M., Voicu, G., Constantin, G. A., Ferdeş, M., \& Ionescu, M. (2015). Falling number vs. liquefaction number in alpha- amylase activityestimation for bakery flour. In G. Paraschiv, I. Pirnă, G. Voicu, S. Biriş, \& V. Vlăduţ (Eds.), Proceedings of the meeting of Agricultural and Mechanical Engineering (ISB-INMA TEH). Bucharest, Romania: ISB-INMA TEH.

Sugri, I., Maalekuu, B. K., Kusi, F., \& Gaveh, E. (2017). Quality and shelf-life of sweet potato as influenced by storage and postharvest treatments. Trends in Horticultural Research, 7(1), 1-10. http://dx.doi. org/10.3923/thr.2017.1.10.

Tan, C., Wei, H., Zhao, X., Xu, C., Zhou, Y., \& Peng, J. (2016). Soluble fiber with high water-binding capacity, swelling capacity, and fermentability reduces food intake by promoting satiety rather than satiation in rats. Nutrients, 8(10), 615. http://dx.doi.org/10.3390/ nu8100615. PMid:27706095.

Teye, E., Agbemafle, R., \& Lamptey, F. P. (2018). Development and examination of sweet potato flour fortified with indigenous underutilized seasonal vegetables. Beverages, 4(1), 5. http://dx.doi. org/10.3390/beverages4010005.

Truong, V. D., Avula, R. Y., Pecota, K. V., \& Yencho, G. C. (2018). Sweet potato production, processing, and nutritional quality. In M. Siddiq (Ed.), Handbook of vegetables and vegetable processing (Chap 35, pp. 811-838). New York: John Wiley and Sons. http:// dx.doi.org/10.1002/9781119098935.ch35.

van Chuyen, H., \& Eun, J. (2013). Nutritional quality of foods: sweet potato. In V. R. Preedy (Ed.), Diet quality: an evidence-based approach (Chap 19, pp. 247-256). New York: Humana Press. http://dx.doi. org/10.1007/978-1-4614-7339-8_19.

van Oirschot, Q. E., Rees, D., \& Aked, J. (2003). Sensory characteristics of five sweet potato cultivars and their changes during storage under tropical conditions. Food Quality and Preference, 14(8), 673-680. http://dx.doi.org/10.1016/S0950-3293(02)00209-4.

Wang, C. H., Ma, Y., Zhu, D., Wang, H., Ren, Y., Zhang, J., Thakur, K., \& Wei, Z. (2017). Physicochemical and functional properties of dietary fiber from Bamboo Shoots (Phyllostachys praecox). Emirates Journal of Food and Agriculture, 29(7), 509-517. http://dx.doi.org/10.9755/ ejfa.2017-02-274.

Wang, S., Nie, S., \& Zhu, F. (2016). Chemical constituents and health effects of sweet potato. Food Research International, 89(1), 90-116. http://dx.doi.org/10.1016/j.foodres.2016.08.032. PMid:28460992. 